Morris, J. G. (1960). J. gen. Microbiol. 22, 564-582

\title{
Studies on the Metabolism of Arthrobacter globiformis
}

\author{
BY J. G. MORRIS* \\ Microbiology Unt, Department of Biochemistry, University of Oxford
}

\begin{abstract}
SUMMARY: A strain of Arthrobacter globiformis grew on a glucose + ammonium + salts medium ( $\mathrm{pH} 7$ ) when this was supplemented with biotin $\left(10^{-8} \mathrm{M}\right)$. Maximal and most rapid growth was obtained by aerobic incubation in shaken culture at $30^{\circ}$. A variety of sugars, sugar alcohols, dicarboxylic acids, some amino acids and miscellaneous compounds could replace the glucose in this medium, but various aromatic compounds, purines, pyrimidines and other amino acids did not support growth, though several of these substances were oxidized by washed suspensions. The organism was an obligate aerobe whose terminal electron transport was mediated by a cytochrome system. Enzymic analysis showed that glucose could be metabolized by the hexose monophosphate oxidation and Embden-Meyerhof pathways. No direct oxidation of glucose to gluconic and 2-oxogluconic acids, and no Entner-Doudoroff pathway for the utilization of 6-phosphogluconate were demonstrable. Studies with differently $\left[{ }^{14} \mathrm{C}\right]$-labelled samples of glucose confirmed these findings and showed that in suspensions of organisms depleted of endogenous metabolites, the EmbdenMeyerhof pathway was fully functional, accounting for $c .65 \%$ of glucose utilization, the remaining $35 \%$ proceeding by way of the hexose monophosphate cycle. The pyruvate so formed was normally further oxidized by the tricarboxylic acid cycle. The growth yield of $\boldsymbol{A}$. globiformis on limiting amounts of glucose was no greater than that of Escherichia coli under the same condition. These observations are considered in relation to the allocation of $A$. globiformis in the autochthonous group of soil micro-organisms.
\end{abstract}

Arthrobacter globiformis is the type species of a comparatively recently distinguished genus of soil coryneform bacteria (Conn \& Dimmick, 1947). The biochemistry of members of this genus has been little studied apart from some early observations of the then Bacterium globiformis which chiefly served to emphasize its ready growth on simple media, 'physiological instability' and economical use of substrates (Conn, 1928; Conn \& Darrow, 1935; Taylor \& Lochhead, 1937; Taylor, 1938). Studies of various aspects of the metabolism of other species have generally been made with organisms which were electively isolated from soil by virtue of their ability to oxidize a certain substrate and were only subsequently and incidentally identified as members of the genus Arthrobacter (Dubos \& Miller, 1937; Adams, 1954; Sacks, 1954; Sguros, 1955). Apart from the results obtained with Corynebacterium creatinovorans (now Arthrobacter ureafaciens) by Krebs \& Eggleston (1939) and Ghiretti \& Barron (1954), such studies have little advanced knowledge of the general characteristics of the genus. A detailed study of the general metabolism of the type species might reveal properties other than the tendency to coccoid ('arthrospore') formation which could serve to demarcate the genus more certainly from other genera of similar morphology. The routes whereby glucose is

* Guinness Research Fellow in Microbiological Biochemistry. 
metabolized by the organism, and the overall efficiency of this process, were also investigated in the hope that the results might explain at least in part why $A$. globiformis should be a member of the autochthonous group of soil micro-organisms (Conn, 1948).

\section{METHODS}

Organisms. The stock culture of Arthrobacter globiformis no. 8602 of the National Collection of Industrial Bacteria was maintained on slopes of medium $A$ and subcultured monthly $\left(40 \mathrm{hr}\right.$. at $\left.25^{\circ}\right)$.

The strain of Escherichia coli used was a prototrophic strain (15) from the American Type Culture Collection (no. 9723). It was maintained on tryptic meat agar slopes and subcultured monthly (16 hr. at $\left.37^{\circ}\right)$.

Solid media. Medium A contained (g./l.): nutrient agar ('Oxoid'), 30; yeast extract (Difco), 1; Löhnis soil extract (see below), $500 \mathrm{ml}$. It was sterilized by autoclaving for $20 \mathrm{~min}$. at $115^{\circ}$.

Medium B-agar. Medium B (see below) was solidified by incorporation of $4 \%(w / v)$ agar.

Liquid media. Medium $B$ was prepared at double strength in $500 \mathrm{ml}$. amounts as two solutions $\left(B_{1}\right.$ and $\left.B_{2}\right)$ separately sterilized by autoclaving for 7 min. at $115^{\circ}$ and mixed aseptically when cold; final $\mathrm{pH} 7$. Solution $\mathrm{B}_{1}$ contained (g.): $\mathrm{K}_{2} \mathrm{HPO}_{4}, 7 ; \mathrm{KH}_{2} \mathrm{PO}_{4}, 3$; in $250 \mathrm{ml}$. distilled water. Solution $\mathrm{B}_{2}$ contained (g.): $\mathrm{NH}_{4} \mathrm{Cl}, 3 ; \mathrm{MgSO}_{4} .7 \mathrm{H}_{2} \mathrm{O}, 0.2 ; \mathrm{CaCl}_{2}$ (anhyd.), 0.04 in $200 \mathrm{ml}$. distilled water. Then were added $\mathrm{FeCl}_{3}\left(10^{-2} \mathrm{M}\right)$; trace salts solution (see below), $2 \mathrm{ml}$; biotin (100 $\mu \mathrm{g} . / \mathrm{ml}$.), $0.5 \mathrm{ml}$. The carbon source was added, after separate sterilization, in $50 \mathrm{ml}$. quantities to give a final concentration of $1 \%(\mathrm{w} / \mathrm{v})$. Thus glucose ( $1 \mathrm{~g}$. in $50 \mathrm{ml}$. water) autoclaved for $7 \mathrm{~min}$. at $115^{\circ}$ was added aseptically to otherwise complete medium $\mathbf{B}$.

Supplements. To prepare Löhnis soil extract $500 \mathrm{ml}$. tap water were added to $500 \mathrm{~g}$. garden soil and autoclaved for $30 \mathrm{~min}$. at $121^{\circ}$. The extract was filtered hot through a coarse filter paper, then cold through Whatman no. 1. After dilution to $500 \mathrm{ml}$. a mixture of equal volumes of carbon tetrachloride and toluene was added as preservative and the extract stored at $2^{\circ}$.

The trace salts solution contained (g./l.): $\mathrm{H}_{3} \mathrm{BO}_{3}, 2 \cdot 8 ; \mathrm{MnSO}_{4} \cdot 4 \mathrm{H}_{2} \mathrm{O}, 2 \cdot 1$; $\mathrm{CuSO}_{4} .5 \mathrm{H}_{2} \mathrm{O}, 0 \cdot 2 ; \mathrm{Na}_{2} \mathrm{MoO}_{4} \cdot 2 \mathrm{H}_{2} \mathrm{O}, 0.75 ; \mathrm{CoSO}_{4}, 0 \cdot 24 ; \mathrm{ZnSO}_{4} .7 \mathrm{H}_{2} \mathrm{O}, 0 \cdot 25$, and ethylenediaminetetra acetic acid, $1 \cdot 0$.

Casein hydrolysate (vitamin-free) was prepared by the method of Snell \& Rannefeld (1945).

Static culture. Roux bottles containing $100 \mathrm{ml}$. of medium B agar were inoculated with about $10^{9}$ organisms and incubated for $40 \mathrm{hr}$. at $25^{\circ}$.

Shaken culture. For growth tests, liquid medium $(5 \mathrm{ml}$.) was contained in optically matched $150 \times 150 \times 16 \mathrm{~mm}$. $\perp$-shaped tubes and rocked in a thermostatically controlled water bath (Morris \& Woods, 1959). The inoculum was $0.1 \mathrm{ml}$. of an aqueous suspension of organisms (about $2 \times 10^{7} \mathrm{ml} . /$ ) derived from a $40 \mathrm{hr}$. culture on medium $A$.

When larger quantities of organism were required, Erlenmeyer flasks (2 l.) 
containing $500 \mathrm{ml}$. medium were inoculated with about $2 \times 10^{8}$ organisms and incubated on a rotary shaker (New Brunswick Scientific Co., New Brunswick, N.J., U.S.A.) at $200 \mathrm{rev}$. of radius $1.75 \mathrm{~cm} . / \mathrm{min}$.

Assessment of growth. The extent of growth was measured with an EEL photoelectric colorimeter (Evans Electroselenium Ltd., Halstead, Essex) with a neutral density filter; the uninoculated medium was used to give the zero setting. The cross-arms of the $16 \mathrm{~mm}$. $\perp$-tubes were constructed to fit the instrument; samples of other cultures were assessed in $6 \mathrm{~mm}$. tubes. The relation between instrument reading and dry weight for organisms in the coryneform and coccoid stages of growth differed little and was linear up to a reading of 35-40; a reading of 20 was equivalent to $0.5 \mathrm{mg}$. dry wt. $/ \mathrm{ml}$.

Preparation of cell-free extracts. To prepare cell-free extracts of organisms, washed suspensions (300-400 $\mathrm{mg}$. dry wt. in $10 \mathrm{ml}$.) were subjected to ultrasonic vibration ( $25 \mathrm{kc}$. $/ \mathrm{sec}$. for $15 \mathrm{~min}$.) in a $50 \mathrm{ml}$. stainless steel conical flask transducer. The generator was Mullard Type E 7590/B (Mullard Electronic Equipment, London). The exterior of the flask was cooled with running water so that its contents remained at less than $20^{\circ}$ throughout. Undisrupted organisms and debris were removed by centrifugation $(20,000 \mathrm{~g}$ for 15 min.) at $0^{\circ}$.

Chemical estimations. Ammonia was determined by a modification of the hypochlorite-phenate method (Russell, 1944); glucose by the Nelson modification of the Somogyi method (Nelson, 1944); pyruvate was first converted to its 2:4-dinitrophenylhydrazone (Friedemann \& Haugen, 1943). The Dische (1953) modification of the orcinol reaction was used for the estimation of pentoses. Assay of inorganic phosphate was performed by the method of Berenblum \& Chain (1938). Porphyrins were measured spectrophotometrically in acid solution (Lascelles, 1956). Protein was determined by the FolinCiocalteau procedure (Lowry, Rosebrough, Farr \& Randall, 1951). Triose phosphate was estimated as alkali-labile organic phosphate, i.e. that inorganic phosphate liberated by $\mathrm{N}-\mathrm{KOH}$ ( $20 \mathrm{~min}$. at room temperature).

Enzyme estimations. Kinase activity was usually measured manometrically (Wood, 1955), but hexokinase was also assayed by following reduction of triphosphopyridine nucleotide (TPN) spectrophotometrically at $340 \mathrm{~m} \mu$ (Wood \& Schwerdt, 1953); this method was also used for estimation of glucose-6phosphate dehydrogenase, 6-phosphogluconic dehydrogenase and phosphohexose isomerase (Dawes \& Holms, 1958a). Glyceraldehyde-3-phosphate dehydrogenase was similarly assayed by following the reduction of diphosphopyridine nucleotide (DPN; Dawes \& Holms, 1958 a). Aldolase was assayed by measurement of triose phosphate production from fructose-1:6-diphosphate by cyanide-treated extracts (Taylor, 1955). Lactic dehydrogenase activity was measured by following ( $a$ ) anaerobic reduction of methylene blue (Dixon, 1955), or $(b)$ evolution of $\mathrm{CO}_{2}$ when the following were incubated together at $25^{\circ}$ in $5 \%(\mathrm{v} / \mathrm{v}) \mathrm{CO}_{2}$ in $\mathrm{N}_{2}(\mu \mathrm{mole} / 3 \mathrm{ml}):. \mathrm{NaHCO}_{3}, 150 ; \mathrm{Na}_{3} \mathrm{Fe}(\mathrm{CN})_{6}, 20$;

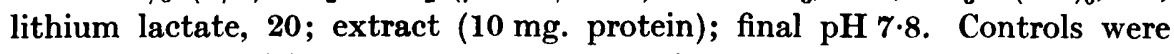
carried out $(a)$ without lactate and $(b)$ with heated extract.

The possible existence of the Entner-Doudoroff pathway, i.e. presence of 
6-phosphogluconic dehydrase and an aldolase for 2-keto-3-deoxy-6-phosphogluconate, was determined by the method of Wood \& Schwerdt (1954).

Full details of the method used to determine the relative importance of the Embden-Meyerhof-Parnas (EMP) and hexose monophosphate (HMP) pathways are given by Dawes \& Holms $(1958 b, 1959)$. The following procedure was adopted in the present work.

Organisms harvested after growth on medium $\mathrm{B}$ agar $\left(40 \mathrm{hr}\right.$. at $\left.25^{\circ}\right)$ were washed twice in $0.05 \mathrm{M}$-phosphate buffer $\left(\mathrm{pH} \mathrm{7.0)}\right.$ with $0.01 \%(\mathrm{w} / \mathrm{v}) \mathrm{MgCl}_{2}$ solution, suspended (equiv. $10 \mathrm{mg}$. dry wt./ml.) in the same buffer and rocked aerobically at $25^{\circ}$ in a large $\perp$-tube. Incubation for at least $8 \mathrm{hr}$. was required to decrease the endogenous metabolism to negligible proportions (i.e. $<2 \%$ of that with glucose). After this time, the organisms were again harvested and washed.

A steady stream of $\mathrm{CO}_{2}$-free air was bubbled through a suspension of these endogenously-depleted organisms (equiv. $600 \mathrm{mg}$. dry wt.) in $10 \mathrm{ml}$. of 0.05 M-phosphate buffer (pH 7.0) containing $2 \mu$ mole arsenite and $100 \mu$ mole of $\left[{ }^{14} \mathrm{C}\right]$ glucose of known specific activity. Samples were withdrawn at intervals during the course of incubation at $25^{\circ}$. Pyruvate formation and glucose disappearance were assayed, and the ${ }^{14} \mathrm{C}$ assimilation by the organisms and the specific activity of the pyruvate were determined.

\section{Isotopic methods}

General counting procedure. Radioactivity was measured with a thin mica end-window Geiger-Muller tube (Type EHM2/5, General Electric Company of England) with quenching probe unit (EKCO Type N558) and decade scaler (ECKO Type N. 530. d, EKCO Electronics Ltd., Southend-on-Sea, Essex). Samples (except ${ }^{14} \mathrm{CO}_{2}$ ) were plated directly on disks of tissue (Green's Lens Tissue no. 105; J. B. Green Ltd., Maidstone, Kent) which covered aluminium planchettes of surface area $3 \cdot 2 \mathrm{~cm} .{ }^{2}$. They were counted for a sufficient time to ensure that the counting error was less than $\pm 1 \%$ (Francis, Mulligan \& Wormall, 1954). With the exception of $\left[{ }^{14} \mathrm{C}\right] \mathrm{BaCO}_{3}$ all samples were of infinite thickness. Background and standard samples were counted at frequent intervals.

Treatment of organisms. On harvesting from reaction mixtures organisms were washed twice with ice-cold water, made up to standard volume and samples equiv. $0.1 \mathrm{mg}$. dry wt. $/ \mathrm{cm} .^{2}$ plated. The self-absorption curve for $\left[{ }^{14} \mathrm{C}\right]$-labelled organisms only departed from linearity with samples of concentration greater than equiv. $\mathbf{0 \cdot 2 3} \mathrm{mg}$. dry wt./cm. ${ }^{2}$.

Glucose. Samples of aqueous solutions were plated directly and carefully dried under an infrared lamp.

Pyruvate. This was isolated as its 2:4-dinitrophenylhydrazone and purified from traces of $\alpha$-oxoglutaric 2:4-dinitrophenylhydrazone by elution of the two main bands obtained by ascending chromatography on Whatman no. 4 paper in the solvent of Dagley, Fewster \& Happold (1952). The hydrazone was plated on the planchettes from aqueous solution and the amounts taken, assayed after counting by measuring the $\mathrm{E}_{\mathbf{4 1 2}}$ and $\mathrm{E}_{\mathbf{4 4 0}}$ values of the solution 
obtained by elution of the planchette contents with $5 \%(w / v)$ sodium carbonate in $0.75 \mathrm{~N}$-sodium hydroxide. For the 2:4-dinitrophenylhydrazone of pyruvate in this solvent the relevant molar extinction coefficients are: $\mathrm{E}_{\mathbf{4 1 2}}=1.1 \times 10^{4}$ and $\mathrm{E}_{440}=1.52 \times 10^{4}$ (Goodwin \& Williams, 1952).

Carboxyl labelling of pyruvate. Pyruvic 2:4-dinitrophenylhydrazone was oxidized with acid permanganate (Krebs, 1938) and the ${ }^{14} \mathrm{CO}_{2}$ trapped in $0.5 \mathrm{~N}-\mathrm{NaOH}$ in vacuo.

${ }^{14} \mathrm{CO}_{2}$. After absorption in alkali this was precipitated as $\left[{ }^{14} \mathrm{C}\right] \mathrm{BaCO}_{3}$ which was then plated on planchettes by filtration (Sakami, 1955). Unlabelled $\mathrm{Na}_{2} \mathrm{CO}_{3}$ was added to the samples to bring each to about $5 \mathrm{mg} . \mathrm{BaCO}_{3} / \mathrm{cm} .{ }^{2}$. Correction was made for self absorption.

Chemicals. Amino acids were all used as the DL-compounds unless otherwise stated. A commercial sample of fructose-1:6-diphosphate (dibarium salt) was purified by the method of Neuberg, Lustig \& Rothenberg (1944). A recrystallized specimen of sodium pyruvate was given by $\mathrm{Dr} R$. Cooper, and a sample of sodium fluoroacetate kindly provided by Mr R. Wakelin. All other compounds were commercial specimens. $\left[\mathrm{U}-{ }^{14} \mathrm{C}\right] \mathrm{G}$ lucose, $\left[\mathrm{1}^{-14} \mathrm{C}\right] \mathrm{glucose}$ and $\left[6-{ }^{14} \mathrm{C}\right]$ glucose were all obtained from the Radiochemical Centre, Amersham, Buckinghamshire, England.

Miscellaneous. Oxygen uptake and carbon dioxide evolution were measured by the usual manometric procedures. Ultraviolet absorption measurements were made using $1 \mathrm{~cm}$. silica cuvettes in the Unicam Model SP 500 spectrophotometer (Unicam Instruments Ltd., Cambridge).

\section{RESULTS}

\section{Nutrition}

Growth of the strain of Arthrobacter globiformis used was only obtainable in media containing biotin $\left(10^{-8} \mathrm{M}\right)$. The optimal temperature for growth was about $30^{\circ}$; good growth took place at $25^{\circ}$ which was used routinely for purposes of comparison with other soil bacteria (Fig. 1). The degree of aeration of the culture had a profound effect on the rate and extent of growth. Under strictly anaerobic conditions no growth was possible. In static liquid culture growth was feeble and the medium became highly viscous, possibly due to the production of extracellular polysaccharide. Best growth occurred in shaken liquid culture or on the surface of solid media.

Both ammonium and nitrate ions were utilized as sources of nitrogen but urea supported only limited growth (equiv. 0.4 mg. dry wt./ml.). Many compounds were utilized in place of glucose as sole source of carbon (Table 1 ). In citrate medium only poor growth was obtained (equiv. $0.2 \mathrm{mg}$. dry wt./ml.) but this was possibly due to the sequestration of ions, for the culture was of abnormal appearance, the organisms being much elongated, markedly clubbed and aggregated in stellate clusters. Media in which one of a number of amino acids served as sole source of both carbon and nitrogen supported good growth of the organism ( $>$ equiv. 1-2 mg. dry wt./ml.) (Table 1). Creatine or hypoxanthine supported slight growth though other purines were not attacked. 
Glucose proved to be one of the best carbon sources, the $\mathrm{pH}$ value of the medium not changing significantly throughout growth.

\section{Oxidative ability of glucose-grown organisms}

Washed suspensions of Arthrobacter globiformis harvested from medium B agar and suspended in $0.05 \mathrm{M}$-phosphate buffer $(\mathrm{pH} 7)$ oxidized a great variety of compounds. These included several substances which were not able to support growth of the organism, some being utilized only after lag periods suggestive of inducible enzyme formation. Some representative $\boldsymbol{Q}_{\mathbf{o}_{2}}$ values are listed in Table 2 . The suspensions used routinely were of the coryneform organisms produced by growth for $40 \mathrm{hr}$. at $25^{\circ}$. Coccoid forms were predominant in older (7- to 10-day) cultures but the oxidative activity of these did not differ markedly from that of younger organisms.

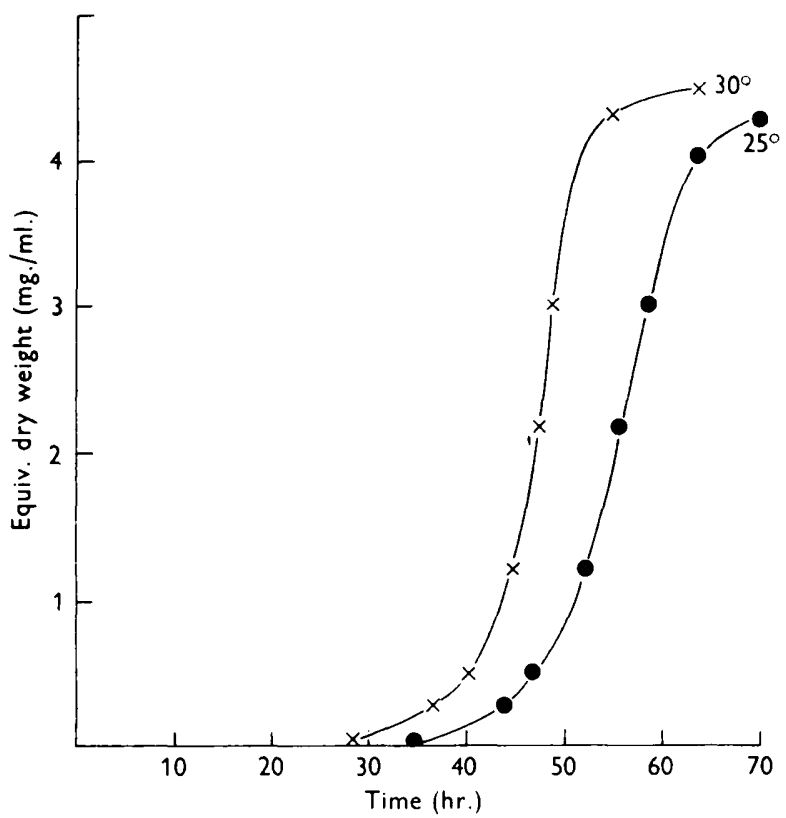

Fig. 1. Growth of Arthrobacter globiformis on medium B containing glucose. Inoculated medium $(5 \mathrm{ml}$.) in $150 \times 150 \times 16 \mathrm{~mm}$. $\perp$-tubes incubated with rocking at temperatures shown.

Many hexoses were oxidized without delay, e.g. mannose, fructose, galactose, sorbose. Some pentoses were utilized only after a lag (L-arabinose, D-xylose, the methylpentose rhamnose), while others were not attacked at all (D-arabinose). Of the disaccharides sucrose but not lactose was readily oxidized. The sugar alcohols mannitol, sorbitol, dulcitol and glycerol were all utilized. All those amino acids which could support growth of Arthrobacter globiformis were oxidized by glucose-grown organisms as were several which would not serve as combined carbon and nitrogen source for growth (tyrosine, phenylalanine, threonine, serine, citrulline and ornithine); amongst others that were not 


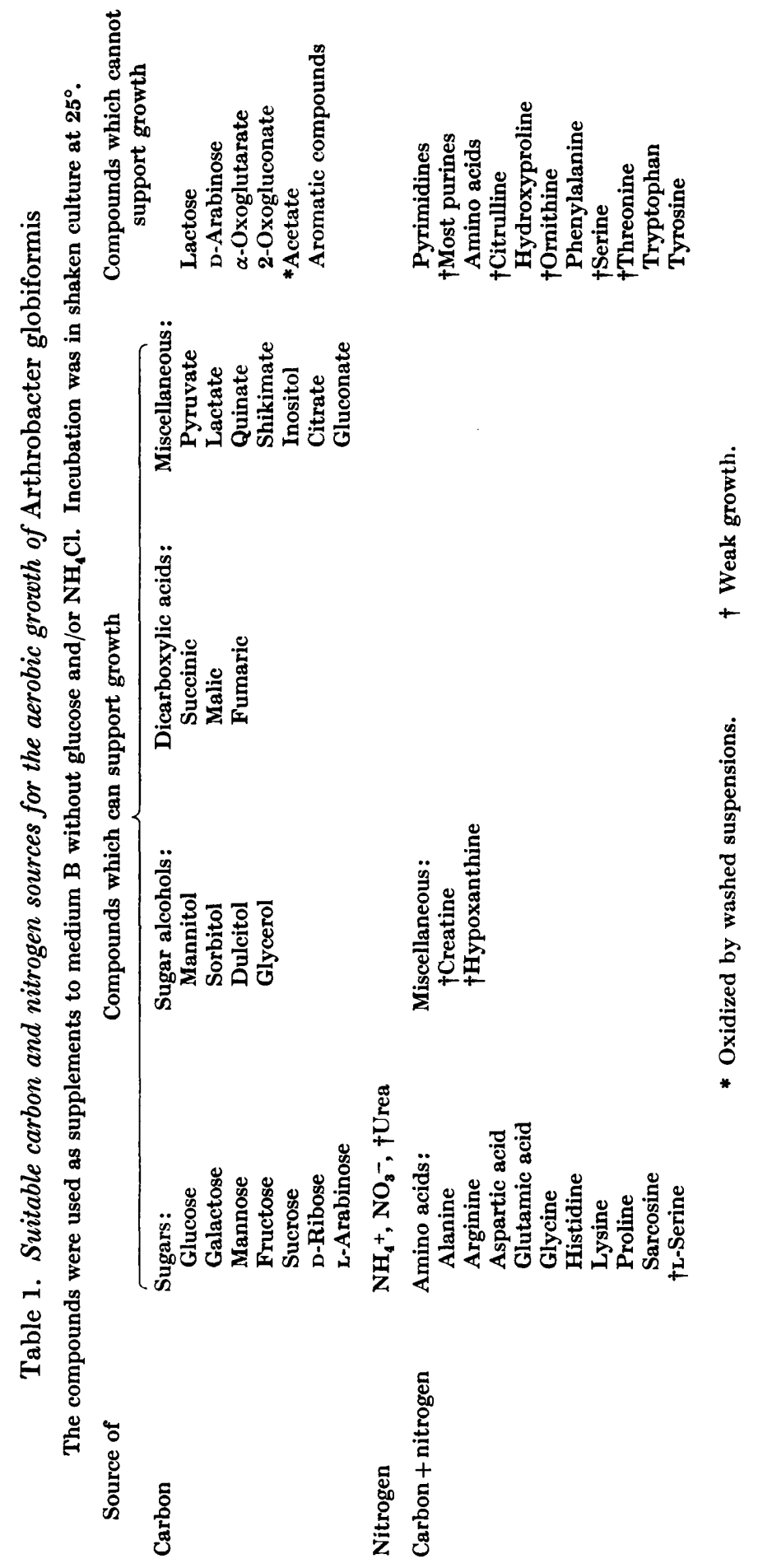


attacked were hydroxyproline, tryptophan and glycocyamine. Pyrimidines were not oxidized but certain purines were, though after some delay (guanine, xanthine, uric acid). Aromatic compounds such as benzoic and mandelic acids and catechol were not attacked nor were the dicarboxylic glutaric, adipic and pimelic acids, though short-chain fatty acids such as propionic and butyric acid were slowly oxidized.

Table 2. Oxidative ability of glucose-grown Arthrobacter globiformis

Manometer flasks shaken in air at $25^{\circ}$ contained $(3 \mathrm{ml}$. final volume): phosphate buffer (pH 7.0), 1.5 mmole; washed organisms harvested from medium $\mathrm{B}$ agar, equiv. $20 \mathrm{mg}$. dry wt.; substrate, $20 \mu$ mole. In centre well, $0 \cdot 2 \mathrm{ml}$. of $20 \%(\mathrm{w} / \mathrm{v}) \mathrm{KOH}$. All values corrected for endogenous $Q_{O_{2}}(4 \cdot 5)$.

\begin{tabular}{lc}
\multicolumn{1}{c}{ Substrate } & $Q_{\mathrm{O}}$ \\
*Glucose & $22 \cdot 0$ \\
Gluconate & $(6 \cdot 0)$ \\
Glucose-6-phosphate & 0 \\
Fructose-1:6-diphosphate & 0 \\
Fructose & $\mathbf{1 6 \cdot 5}$ \\
Arabinose & $4 \cdot 0$ \\
Ribose & $0 \cdot 3$ \\
Mannitol & $20 \cdot 5$ \\
Inositol & $(11 \cdot 0)$ \\
Ethanol & $21 \cdot 0$ \\
Lactate & $22 \cdot 5$
\end{tabular}

( ) Signifies delay in utilization.

* The $Q_{\mathrm{O}_{2}}$ value for glucose varied from one batch of organisms to another (within the limits 18 to 28 ) but $Q_{0}$, values for other substances relative to glucose remained fairly constant.

\section{Terminal respiration}

The cytochrome content of organisms grown on medium B was markedly greater than that of those harvested from medium $B$ not containing ferric chloride. Four absorption bands were visible when thick suspensions or extracts of the organism treated with dithionite were examined in the hand

Table 3. Porphyrin production during growth of Arthrobacter globiformis

Inoculated medium in $150 \times 150 \times 10 \mathrm{~mm}$. $\perp$-tubes was rocked at $25^{\circ}$ until maximal growth was achieved. The degrec of aeration of the culture was inversely proportional to its volume. Supplements : casein hydrolysate, $1 \% ; \mathrm{Fe}$ as $\mathrm{FeCl}_{3}, 10^{-5} \mathrm{M} . \mathrm{B}=$ medium $\mathrm{B}$.

$\begin{array}{lc}\text { Medium } \\ \text { Constituents } & \begin{array}{c}\text { Volume } \\ (\mathrm{ml} .)\end{array} \\ \text { 13-Fe+Casein } & 5 \\ & 10 \\ \mathrm{~B}-\mathrm{Fe} & 15 \\ \mathrm{~B}+\mathrm{Fe} & 10 \\ & 10\end{array}$

$\begin{array}{ccc}\begin{array}{c}\text { Growth } \\ \text { (equiv. mg. }\end{array} & \overbrace{\text { dry wt./ml.) }} & \begin{array}{c}\text { ( } \mu \text { mole/mg. } \\ \text { dry wt. } \\ \text { organism) }\end{array} \\ 4.8 & 8.9 & 1.8 \\ 4.9 & 52.0 & 16.1 \\ 1.3 & 5.4 & 4.2 \\ 1.8 & 1.1 & 0.6 \\ 2.2 & 0.3 & 0.1\end{array}$


spectroscope. The strongest of these was that of a b-type cytochrome (at $560 \mathrm{~m} \mu$ ) the others being less distinct at about 530-540, 590-600 and 620$630 \mathrm{~m} \mu$. Respiration of suspensions was almost completely inhibited by $10^{-3} \mathrm{M}$-cyanide and it seems likely that cytochromes mediate the ultimate transfer of electrons in this organism.

Porphyrin production. Besides containing cytochromes the organism was strongly catalase-positive, and under certain cultural conditions excreted porphyrin (mainly coproporphyrin III) in quite large amount. Omission of iron from the medium increased the yield of porphyrin (cf. Lascelles, 1956) which was also greater when the basal medium was supplemented with casein hydrolysate (Table 3). The degree of aeration greatly influenced porphyrin production (Table 3). Cultures of Arthrobacter globiformis incubated with shaking but under conditions of limited aeration in medium B + casein hydrolysate but without iron produced free porphyrin up to $50 \mu \mathrm{mmole} / \mathrm{ml}$., imparting a deep red colour to the medium.

\section{Metabolism of glucose}

In an early study of Bacterium globiformis it was reported that the organism was particularly efficient in its utilization of glucose. Few if any side products were excreted in a series of experiments in which between 80 and $130 \%$ of supplied glucose was accounted for as cell substance $+\mathrm{CO}_{2}$ (Conn \& Darrow, 1935). An unusually efficient utilization of glucose, if confirmed, might result from the participation of a novel pathway in its metabolism or might be due to more efficient operation of routes common to more profligate organisms. These possibilities were investigated.

Table 4. Efficiency of conversion of glucose into cell material by Arthrobacter globiformis and Escherichia coli

Inoculated medium B (5 ml.) with glucose as shown, was rocked in $\perp$-tubes until maximal growth was achieved.

\begin{tabular}{|c|c|c|c|c|}
\hline Organism & $\begin{array}{c}\text { Temperature } \\
\text { of } \\
\text { incubation }\end{array}$ & $\begin{array}{c}\text { Glucose } \\
\text { (mg./ml.) }\end{array}$ & $\begin{array}{l}\text { Organisms } \\
\text { (equiv. } \\
\text { dry wt. } \\
\text { mig./ml.) }\end{array}$ & $\begin{array}{l}\text { Molar growth } \\
\text { yield } \\
\mu \mathrm{g} \text {. organism } \\
\mu \text { mole glucose }\end{array}$ \\
\hline Arthrobacter globiformis & $30^{\circ}$ & $\begin{array}{l}3 \\
1 \\
0 \cdot 3\end{array}$ & $\begin{array}{l}1 \cdot 5 \\
0 \cdot 52 \\
0 \cdot 16\end{array}$ & $\begin{array}{l}90 \\
94 \\
96\end{array}$ \\
\hline Escherichia coli & $37^{\circ}$ & $\begin{array}{l}3 \\
1 \\
0 \cdot 3\end{array}$ & $\begin{array}{l}1 \cdot 45 \\
0 \cdot 52 \\
0 \cdot 15\end{array}$ & $\begin{array}{l}87 \\
94 \\
90\end{array}$ \\
\hline
\end{tabular}

\section{Efficiency of glucose utilization}

Arthrobacter globiformis grown under otherwise optimal conditions in medium B containing a growth-limiting concentration $(3 \mathrm{mg} . / \mathrm{ml}$.$) of \left[\mathrm{U}-{ }^{14} \mathrm{C}\right]-$ glucose, converted $57 \%$ of this into cell substance and $32 \%$ into carbon dioxide. Only $11 \%$ of the initial radioactivity remained in the culture filtrate at the end of growth and after acidification to release $\mathrm{C}^{\mathrm{O}} \mathrm{O}_{2}$. The extent of grow th 
of Arthrobacter globiformis and Escherichia coli on limiting glucose concentrations when measured under otherwise optimal conditions of growth were found to be very similar (Table 4).

\section{Routes of glucose utilization}

Glucose was not utilized anaerobically by washed suspensions of Arthrobacter globiformis. Similarly, no $\mathrm{CO}_{2}$ evolution occurred when whole organisms or ultrasonic extracts were incubated anaerobically with glucose in bicarbonate buffer. Aerobically, washed suspensions rapidly oxidized glucose $\left(Q_{\mathbf{0}_{\mathbf{z}}}^{25^{\circ}}=22\right)$ with an R.Q. of 1.0. Only about 2 mole $\mathrm{O}_{2}$ were utilized for each mole glucose which disappeared from the medium. No major product other than carbon dioxide was detected; it was concluded that appreciable glucose assimilation was occurring. Thus dinitrophenol $\left(10^{-3} \mathrm{M}\right)$ increased the $\mathrm{O}_{2}$ uptake to 45 mole/mole glucose utilized. Glucose assimilation determined under these conditions with $\left[\mathrm{U}^{14} \mathrm{C}\right]$ glucose was found in fact to account for the bulk of the glucose utilized.

\section{Table 5. Products of glucose utilization by arsenite-inhibited suspensions of Arthrobacter globiformis}

A washed suspension of $\mathcal{A}$. globiformis (equiv. $30 \mathrm{mg}$. dry wt.) in $3 \mathrm{ml}$. of $5 \times 10^{-2} \mathrm{M}$ phosphate buffer ( $\mathrm{pH} \mathrm{7.0)}$ with sodium arsenate $\left(2 \times 10^{-4} \mathrm{M}\right)$, was incubated aerobically at $25^{\circ}$ with $10 \mu$ mole [U-14 C ] glucose (specific activity, 9.5 $\times 10^{8}$ c.p.m./ $/$ mole) until all the glucose was utilized.

$\begin{array}{ccc}\text { Product } & \overbrace{\begin{array}{c}\text { (As } \begin{array}{c}\%+\text { glucose } \\ \text { utilized })\end{array} \\ \text { Assimilated material }\end{array}}^{\text {Radioactivity }} \\ \text { Carbon dioxide } & 3.52 & 37 \cdot 0 \\ \text { Pyruvate } & 1.48 & 15 \cdot 6 \\ \quad \text { Total } & 4.09 & 43 \cdot 0 \\ & 9.09 & 95 \cdot 6\end{array}$

Oxidation of glucose by washed suspensions of the organism was inhibited by arsenite, $5 \times 10^{-4} \mathrm{M}$ causing $50 \%$ inhibition of $\mathrm{O}_{2}$ uptake. Under these conditions the $\mathrm{pH}$ value of the medium was decreased by the accumulation of pyruvic acid together with trace amounts of $\alpha$-oxoglutaric acid. Virtually all $(96 \%)$ of the supplied glucose could be accounted for as assimilated material, liberated $\mathrm{CO}_{2}$ and excreted pyruvate (Table 5). It thus appears that all routes of glucose utilization in the organism lead to pyruvate. At least four pathways have been demonstrated to effect this conversion in various aerobic bacteria (Fig. 2).

Direct oxidation. This pathway would convert glucose first to gluconic acid and possibly further to 2-oxogluconate. Such reactions have been demonstrated in species of Acetobacter and Pseudomonas but no evidence could be obtained of their operation in Arthrobacter globiformis. The complete absence of acid formation during glucose oxidation by washed suspensions would argue against the operation of this pathway, which is the cause of excretion of the intermediate acids by many organisms. Further, $A$. globiformis would not 
grow on 2-oxogluconate though it could use gluconate as sole carbon source for growth. Extracts of gluconate-grown organisms possessed gluconokinase activity which was not demonstrable in similar extracts of glucose-grown organisms (Fig. 3), i.e. the gluconokinase is an inducible enzyme. The nonproduction of gluconokinase during growth of the organism on glucose suggests that free gluconic acid is not a major intermediate in its metabolism. It was concluded that direct oxidation makes no significant contribution to glucose utilization in $\boldsymbol{A}$. globiformis.

Phosphorylative pathways. The rate of glucose oxidation by Arthrobacter globiformis was much decreased by dialysis for $12 \mathrm{hr}$. of a washed suspension of organisms against running distilled water. Addition of inorganic phosphate accelerated subsequent utilization of added glucose by these organisms. Ultrasonic extracts of $\boldsymbol{A}$. globiformis harvested from lactate, gluconate or glutamate

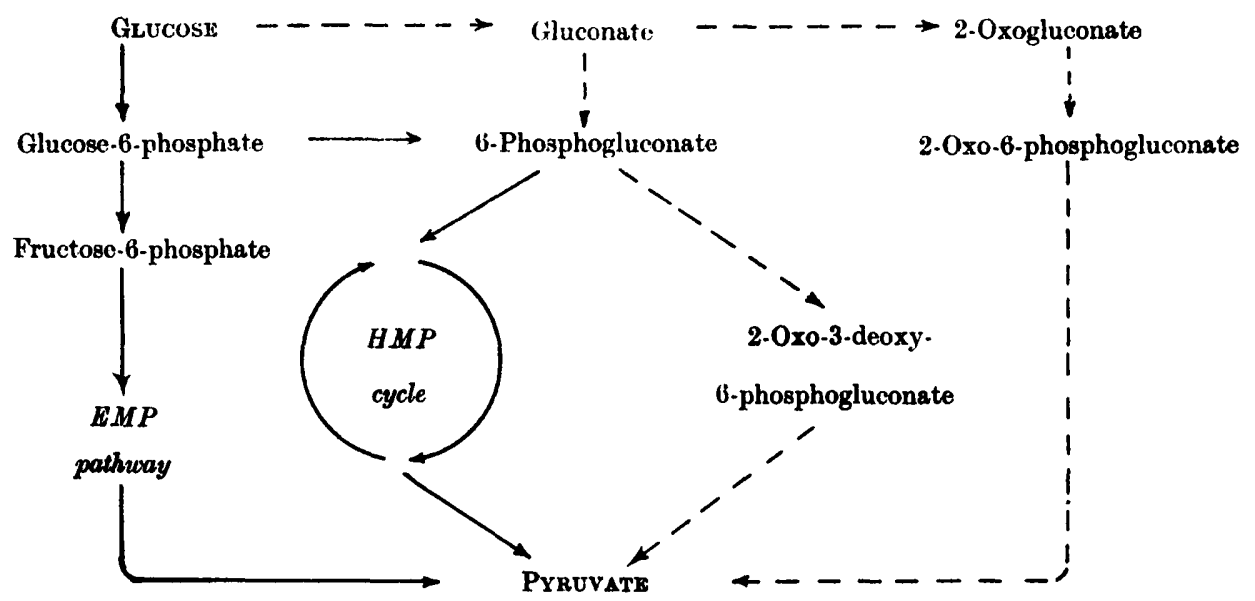

Fig. 2. Known routes available for production of pyruvate from glucose. Uninterrupted lines indicate those operative in Arthrobacter globiformis.

media, as well as from glucose medium, possessed a potent hexokinase which appeared to be constitutive and could undertake the primary phosphorylative step in glucose metabolism in this organism (Fig. 3). The product (glucose-6phosphate) might then be converted to pyruvate by the Embden-MeyerhofParnas (EMP) pathway or it might have to undergo preliminary oxidation to give 6-phosphogluconate.

Embden-Meyerhof-Parnas pathway. Ultrasonic extracts of glucose-grown Arthrobacter globiformis produced pyruvate from: (a) 3-phosphoglyceric acid + ADP; $(b)$ fructose-1:6-diphosphate + ADP; $(c)$ glucose + ATP, when incubated in phosphate buffer containing DPN + arsenite (Table 6). From the ability of these extracts to convert 3-phosphoglyceric acid to pyruvate it was assumed that they contained those enzymes usually responsible for carrying out this conversion, i.e. phosphoglyceromutase, enolase and pyruvic phosphokinase. All the remaining enzymes of the EMP pathway excepting phosphohexokinase could be directly demonstrated in extracts, i.e. isomerase, aldolase, 
triose phosphate dehydrogenase and phosphoglyceric phosphokinase. When extracts were tested for phosphohexokinase activity by the usual manometric method only slight evolution of $\mathrm{CO}_{2}$ was observed. However, the organism in washed suspension $+5 \times 10^{-4} \mathrm{M}$-iodoacetate incorporated label from [U-14 $\mathrm{C}$ -
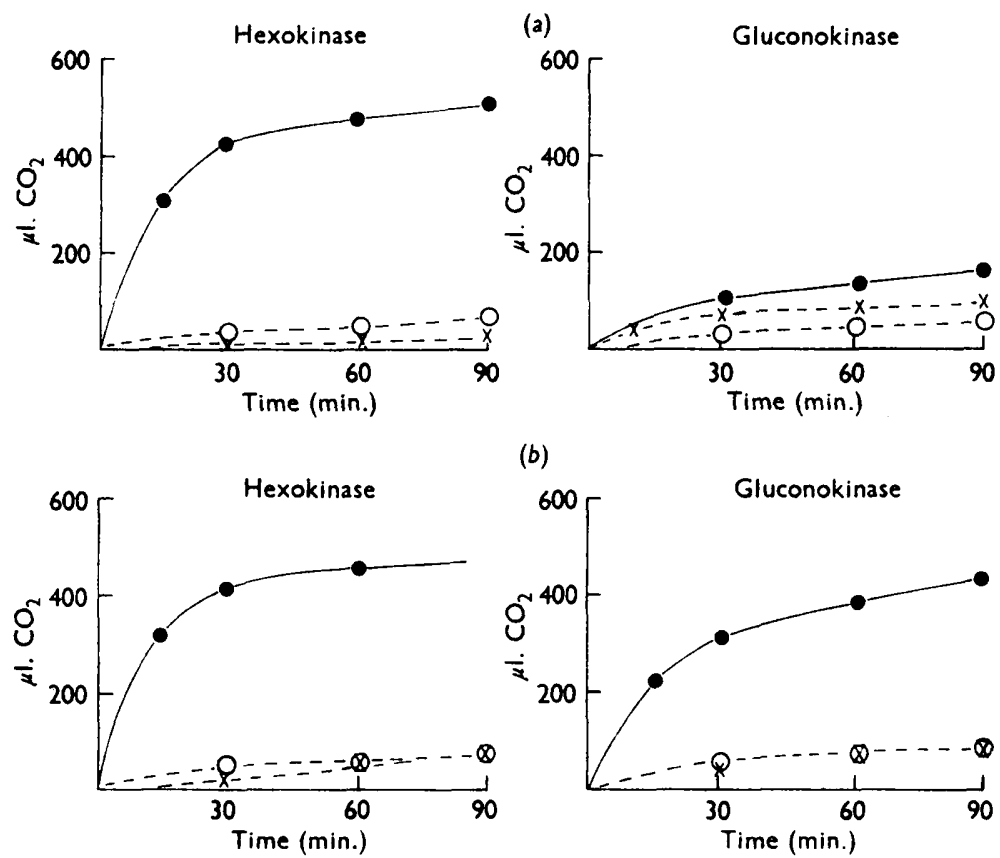

Fig. 3. Gluconokinase and hexokinase activities of extracts of Arthrobacter globiformis grown on $(a)$ glucose and $(b)$ gluconate. Manometer flasks shaken at $25^{\circ}$ contained as indicated ( $\mu \mathrm{mole} / 3 \mathrm{ml}$ ) : $\mathrm{NaHCO}_{3}, 100 ; \mathrm{MgCl}_{2} .6 \mathrm{H}_{2} \mathrm{O}, 30$; substrate glucose or gluconate, 30; ATP, 30 and NaF, 300; extract, $20 \mathrm{mg}$. protein. Atmosphere was $5 \%$ (v/v) $\mathrm{CO}_{2}$ in $\mathbf{N}_{2}$. Final pH $\mathbf{7 \cdot 6}$. Glucose or gluconate, $\times-\cdots \times$; ATP, $O---O$; glucose or gluconate + ATP,

Table 6. Pyruvate production by extracts of glucose-grown

Arthrobacter globiformis

Incubation mixture ( $5 \mathrm{ml}$.) contained ( $\mu$ mole) glycyl-glycine buffer (pH 7.4), 500; DPN, 50; sodium arsenite, 50 ; other substrates, 25 ; extract (20 $\mathrm{mg}$. protein). Incubation was for 1 hr. at $25^{\circ}$ in standing $130 \times 16 \mathrm{~mm}$. tubes.

\section{Substrates}

Glucose + ATP

Fructose-1: 6-diphosphate + ADP

3-Phosphoglyceric acid + ADP

\section{Pyruvate \\ formed \\ ( $\mu$ mole)}

$3 \cdot 5$

$6 \cdot 5$

9.0

glucose into a fraction which was co-precipitated (as the barium salt) with carrier fructose-1:6-diphosphate added to subsequently prepared ultrasonic extracts of these organisms. The specific activity of the product remained practically unchanged after purification by reprecipitation from cold ethanol. 
The probable operation of the EMP pathway in this organism was further suggested by the inhibitory action of iodoacetate $\left(2 \times 10^{-4} \mathrm{M}\right)$ which caused $\mathbf{7 2} \%$ inhibition of glucose oxidation (Table 7). However, high concentrations of fluoride were completely without effect (Table 7). A similar finding with Sarcina lutea gave rise to the suggestion that the enolase of this latter organism might be activated by manganese ions (Dawes \& Holms, 1958a).

Table 7. Effect of inhibitors on rate of glucose oxidation by whole organisms of Arthrobacter globiformis

Assessed manometrically using washed suspensions of glucose-grown A. globiformis. Details as in Table 2.

$\begin{array}{lcc}\text { Compound } & \begin{array}{c}\text { Conc. } \\ (\mathrm{y})\end{array} & \begin{array}{c}\text { Inhibition } \\ (\%)\end{array} \\ \text { Arsenite } & \mathbf{2} \times \mathbf{1 0}^{-3} & \mathbf{5 4} \\ \text { Cyanide } & 10^{-3} & \mathbf{9 2} \\ \text { Fluoroacetate } & \mathbf{8} \times \mathbf{1 0}^{-4} & \mathbf{2 3} \\ \text { Iodoacetate } & \mathbf{2} \times \mathbf{1 0}^{-\mathbf{4}} & \mathbf{7 2} \\ \text { Fluoride } & 10^{-1} & 0\end{array}$

Of particular interest in view of the inability of extracts of Arthrobacter globiformis to ferment glucose anaerobically was their possession of a DPNlinked glyceraldehyde-3-phosphate dehydrogenase and of a lactic dehydrogenase which could utilize ferricyanide or methylene blue, but not DPN, as hydrogen acceptor. Mere addition of muscle lactic dehydrogenase, however, did not initiate glycolysis by these extracts.

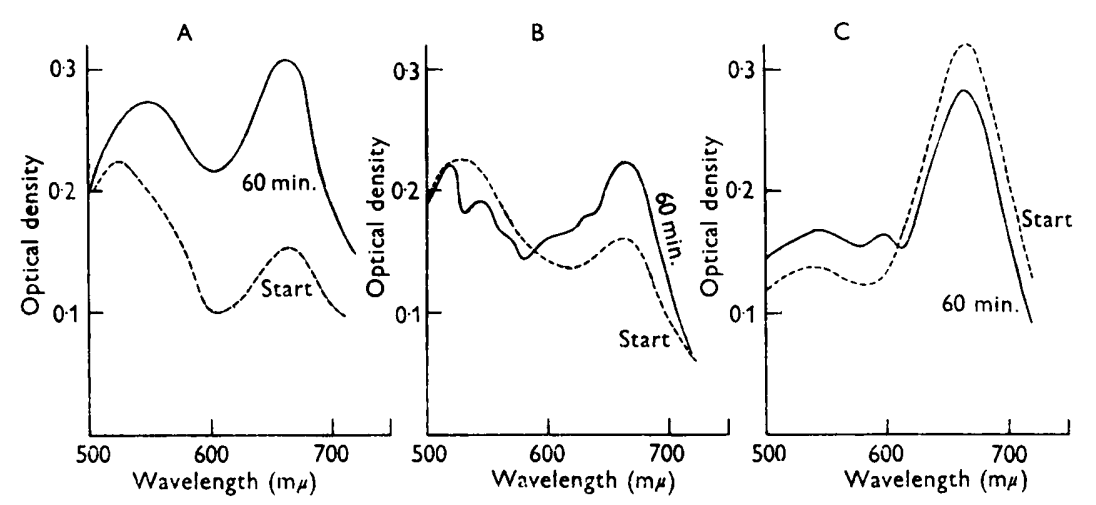

Fig. 4. Absorption spectra of colours given in the orcinol reaction by samples withdrawn at start and after $60 \mathrm{~min}$. at $25^{\circ}$ from: A, suspension of organisms (25 mg./ml.) with $10^{-2} \mathrm{M}$-glucose ; B, extract (10 mg. $/ \mathrm{ml}$. protein) with $10^{-2} \mathrm{M}-6-\mathrm{PO}_{4}$-gluconate; C, extract (10 mg./ml. protein) with $3.8 \times 10^{-3} \mathrm{M}$-ribose-5-PO $\mathrm{PO}_{4}$

Pathways from 6-phosphogluconate. Extracts of glucose-grown Arthrobacter globiformis contained a TPN-dependent glucose-6-phosphate dehydrogenase. The 6-phosphogluconate so formed might be further utilized by at least two routes (Fig. 2).

In the Entner-Doudoroff pathway 6-phosphogluconate is dehydrated to 2-keto-3-deoxy-6-phosphogluconate which is then split to pyruvate and triose 
phosphate. The presence of the enzymes responsible for these reactions could not be demonstrated in extracts of Arthrobacter globiformis.

When glucose was oxidized by thick suspensions of Arthrobacter globiformis trace amounts of pentoses appeared in the medium (Fig. 4A). Similarly, pentose was produced when ultrasonic extracts of the organism were incubated with 6-phosphogluconate (Fig. 4B). Some ketopentose (presumably ribulose and xylulose phosphates) was formed when the extracts were incubated with ribose-5-phosphate (Fig. 4C), though more convincing evidence of the operation of the HMP cycle was the concurrent formation of glucose-6phosphate (Fig. 5). Ghiretti \& Barron (1954), finding Corynebacterium creatinovorans to possess all the constituent enzymes of the EMP pathway, concluded that this could not however be functional since whole organisms and extracts were unable to attack glucose anaerobically. Several investigators have since shown the EMP pathway to be fully operative in organisms which cannot metabolize glucose anaerobically (e.g. Hill \& Mills, 1954, with Pasteurella tularensis; Dawes \& Holms, 1958a, with Sarcina lutea). From the enzymic studies reported above, it was concluded that glucose utilization by Arthrobacter globiformis proceeds by way of both EMP and HMP pathways.

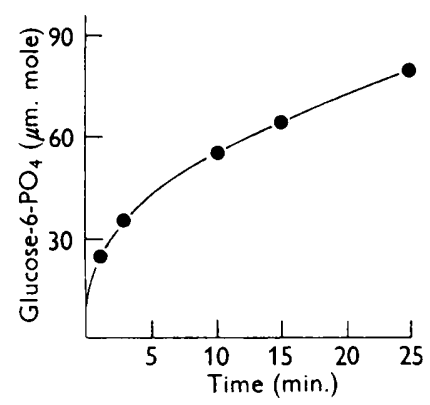

Fig. 5

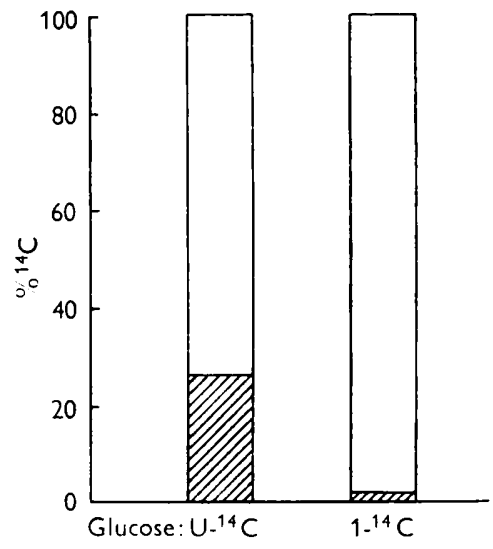

Fig. 6

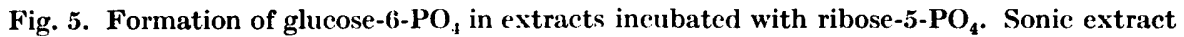
(15 mg. protein) prepared in $150 \mu$ mole phosphate buffer ( $\mathrm{pH} 7$ ) incubated in $3 \mathrm{ml}$. final vol. in cuvette with $10 \mu$ mole ribose-5- $\mathrm{PO}_{4}$ for $10 \mathrm{~min}$. at $\mathbf{2 5}^{\circ}$. Then excess glucose-6-PO dehydrogenase and $2 \mu$ mole TPN added. Controls $(a)$ boiled extract, $(b)$ minus ribose$5-\mathrm{PO}_{4}$. Increase in optical density at $340 \mathrm{~m} \mu$ plotted in terms of glucose-6-PO $\mathrm{P}_{4}$ formed.

Fig. 6. Fraction of ${ }^{14} \mathrm{C}$ present in pyruvate formed from $\left[\mathrm{C}^{\mathrm{1}}{ }^{14} \mathrm{C}\right]$ - and $\left[1^{-14} \mathrm{C}\right]$ glucose which is localized in carboxyl group. Carboxyl ${ }^{14} \mathrm{C}=\mathrm{Q} ;{ }^{14} \mathrm{C}$ in $\mathrm{C}-2+\mathrm{C}-3=\square$.

\section{Relative importance of EMP and HMP pathways}

Two main methods are available to determine the contributions of the EMP and HMP pathways, both methods being dependent upon the use of specifically $\left[{ }^{14} \mathrm{C}\right]$-labelled samples of glucose. In the first method, which is usually to be preferred because of its possible application to normally growing cultures, time lapse studies of ${ }^{14} \mathrm{CO}_{2}$ evolution are performed during oxidation 
of labelled glucose (Wang et al. 1958). The alternative method is based on the analysis of the ${ }^{14} \mathrm{C}$ content and distribution in a product common to both routes. A method in which pyruvate is accumulated, isolated and so analysed was devised by Dawes \& Holms $(1958 b, 1959)$. Briefly the method consists of incubating endogenously-depleted organisms with [ $\left.{ }^{14} \mathrm{C}\right]$-labelled glucose in the presence of a partially inhibitory concentration of arsenite. The excreted pyruvate is isolated as its 2:4-dinitrophenylhydrazone and its specific activity determined. Estimation of the proportion of its ${ }^{14} \mathrm{C}$ content which is located in its carboxyl group allows correction to be made for carboxylation-decarboxylation exchange reactions, and when $\left[1^{-14} \mathrm{C}\right]$ glucose is used as substrate enables an unequivocal decision to be made as to the existence of the Entner-Doudoroff pathway. The ratio: $\frac{\text { corrected specific activity of pyruvate product }}{\text { specific activity of substrate glucose }}$

is related to the apparent fraction of pyruvate molecules formed which are $\left[{ }^{14} \mathrm{C}\right]$-labelled. By calculation, assuming the operation of EMP and HMP pathways only, curves may be constructed to relate this figure to the $\%$ contribution of the HMP pathway to the total metabolism of the substrate glucose. The shape of these standard curves varies with the position of the ${ }^{14} \mathrm{C}$ label in the glucose. Once it has been ascertained with $\left[\mathrm{U}_{-}{ }^{14} \mathrm{C}\right] \mathrm{glucose}$ that the endogenous contribution to pyruvate formation is negligible, and with $\left[1{ }^{14} \mathrm{C}\right]$ glucose that the Entner-Doudoroff pathway is not operative, then those results obtained with $\left[1^{14} \mathrm{C}\right]$ glucose are the most likely to be satisfactory over the whole possible range of HMP participation.

\section{Table 8. Pyruvate production from glucose by arsenite-inhibited suspensions of Arthrobacter globiformis}

A washed suspension of endogenously-depleted, glucose-grown A. globiformis (equiv. $600 \mathrm{mg}$. dry wt.) in $10 \mathrm{ml}$. $0.05 \mathrm{~m}$-phosphate buffer $(\mathrm{pH} 7$ ) with $2 \mu$ mole sodium arsenite and $100 \mu$ mole [U-14 C]glucose (specific activity $9.97 \times 10^{3}$ c.p.m. $/ \mu$ mole), was aerated at $25^{\circ}$ and sampled at times shown.

\begin{tabular}{|c|c|c|c|c|c|c|c|}
\hline \multirow[b]{3}{*}{$\begin{array}{l}\text { Time } \\
\text { (min.) }\end{array}$} & \multirow{3}{*}{$\begin{array}{c}\text { Glucose in } \\
\text { super- } \\
\text { natant } \\
\text { fluid } \\
\text { ( } \mu \text { mole) }\end{array}$} & \multicolumn{4}{|c|}{ Glucose } & \multirow[b]{3}{*}{$\begin{array}{l}\text { Pyruvate } \\
\text { formed } \\
\text { ( } \mu \text { mole) }\end{array}$} & \multirow[b]{3}{*}{$\begin{array}{l}\text { Ratio: } \\
\text { Pyruvate formed } \\
\text { Glucose oxidized }\end{array}$} \\
\hline & & & Assir & lated & & & \\
\hline & & $\begin{array}{l}\text { Radioactivity } \\
\text { in organisms } \\
\text { (c.p.m. } \times 10^{-8} \text { ) }\end{array}$ & ( $\mu$ mole) & $\begin{array}{c}\text { as } \% \text { of } \\
\text { total } \\
\text { utilized }\end{array}$ & $\begin{array}{l}\text { Oxidized } \\
\text { ( } \mu \text { mole })\end{array}$ & & \\
\hline o & 100 & - & - & - & $\rightarrow$ & - & - \\
\hline 5 & 79 & $89 \cdot 5$ & 9 & 43 & 12 & 18 & 1.5 \\
\hline 10 & 60 & 173 & $17 \cdot 4$ & 43 & 22.7 & 33 & $1 \cdot 45$ \\
\hline 15 & 40 & 220 & 22.4 & 37 & $37 \cdot 6$ & 49 & $1 \cdot 30$ \\
\hline 20 & 22 & 294 & $29 \cdot 5$ & 38 & 48.5 & 65.5 & $1 \cdot 35$ \\
\hline 30 & Trace & 360 & 36.2 & 36 & 63.8 & 85.7 & 1.34 \\
\hline
\end{tabular}

When a suspension of endogenously depleted Arthrobacter was incubater with $\left[\mathrm{U}-{ }^{14} \mathrm{C}\right]$ glucose and arsenite (see Methods) the fraction of utilized glucose which was assimilated remained constant $(37 \%)$ while substrate glucose was available, i.e. throughout the first $30 \mathrm{~min}$. of incubation at $\mathbf{2 5}^{\circ}$ (Table 8 ). The ratio pyruvate produced : glucose oxidized $(1 \cdot 3: 1)$ also remained constant du ring 


\section{Metabolism of Arthrobacter globiformis}

this period (Table 8) as did the $\%$ of these pyruvate molecules bearing label $(98 \%$; Table 9$)$. The experiment was repeated with $\left[1^{-14} \mathrm{C}\right]$ and $\left[6{ }^{-14} \mathrm{C}\right]$ samples of glucose (Table 9). Analysis of the ${ }^{14} \mathrm{C}$ content of the carboxyl group of pyruvate derived from $\left[1^{14} \mathrm{C}\right]$ glucose confirmed the absence of the Entner Doudoroff pathway (Fig. 6). Some $30 \%$ of the pyruvate molecules formed during utilization of the $\left[1-{ }^{14} \mathrm{C}\right]$ glucose were labelled. This corresponds to about $35 \%$ utilization of the glucose by the HMP pathway and $65 \%$ by the EMP pathway (Dawes \& Holms, 1958b, 1959).

\section{Table 9. Formation of $\left[{ }^{14} \mathrm{C}\right]$ pyruvate from variously $\left[{ }^{14} \mathrm{C}\right]$-labelled} samples of glucose by Arthrobacter globiformis

A washed suspension of endogenously-depleted (8 hr.) A. globiformis was incubated with $\left.{ }^{14} \mathrm{C}\right]$ glucose in the presence of arsenite for $25 \mathrm{~min}$. at $25^{\circ}$. For details see Methods.

\begin{tabular}{|c|c|c|c|c|}
\hline \multicolumn{2}{|c|}{ Glucose } & \multirow{2}{*}{\multicolumn{2}{|c|}{$\begin{array}{c}\text { Pyruvate } \\
\text { Specific activity } \\
\text { (c.p.m./ } / \text { mole) }\end{array}$}} & \multirow{3}{*}{$\begin{array}{c}\text { Proportion of } \\
\text { pyruvate } \\
\text { molecules } \\
\text { bearing label } \\
(\%)\end{array}$} \\
\hline \multirow[b]{2}{*}{ Label } & \multirow{2}{*}{$\begin{array}{c}\text { Specific } \\
\text { activity } \\
\text { (c.p.m./ } / \mu \text { mole) }\end{array}$} & & & \\
\hline & & Measured & Corrected & \\
\hline $\mathrm{U}-{ }^{14} \mathrm{C}$ & 10,140 & 4,280 & 4,949 & 98 \\
\hline $1-14 \mathrm{C}$ & 916 & 305 & 302 & 30 \\
\hline $6.14 \mathrm{C}$ & 973 & 540 & 480 & 50 \\
\hline
\end{tabular}

Table 10. Oxidation of tricarboxylic acid cycle intermediates by suspensions of glucose-grown Arthrobacter globiformis

\begin{tabular}{lccc} 
Details as in Table 2. Endogenous $Q_{\mathrm{O}_{2}}$ values subtracted \\
\multicolumn{1}{c}{ Substrate } & $Q_{\mathrm{O}_{2}}$ & Substrate & $Q_{\mathrm{O}_{2}}$ \\
Glucose & 22 & Succinate & $16 \cdot 5$ \\
Acetate & 18 & Fumarate & 13 \\
Pyruvate & 21 & Malate & $11 \cdot 5$ \\
Citrate & $(11)$ & Oxalacetate & $\mathbf{9 \cdot 5}$ \\
$\alpha$-Oxoglutarate & 2 & &
\end{tabular}

( ) Signifies delay in utilization.

The result obtained with $\left[6^{-14} \mathrm{C}\right]$ glucose (i.e. $50 \%$ labelling of pyruvate) was indecisive, for over the range up to $40 \%$ HMP pathway contribution, only half of the pyruvate arising from glucose labelled in (-6 was labelled. Thus it can only be concluded that this result, which indicates that the HMP pathway contribution was less than $40 \%$, is not at variance with the more accurate figure of $35 \%$ obtained with $\left[1^{-14} \mathrm{C}\right]$ glucose. It was, however, surprising to find that the carboxyl group of pyruvate derived from $\left[6-{ }^{14} \mathrm{C}\right] \mathrm{glucose}$ was more strongly labelled than that arising from $\left[1{ }^{-14} \mathrm{C}\right]$ glucose (Table 9).

Further fate of pyruvate. It is probable that further metabolism of pyruvate proceeds by the tricarboxylic acid cycle. Growth was possible upon several of the dicarboxylic acids of the cycle and upon citrate itself, though here to an extent probably limited by ion deficiencies. Most of the TCA cycle intermediates were oxidized by suspensions of glucose-grown organisms (Table 10). The exception was $\alpha$-oxoglutarate, against which there seemed to operate a permeability barrier; in suspensions oxidizing pyruvate, $\alpha$-oxoglutarate was 
actually excreted into the medium. No malonate inhibition of respiration was demonstrated, for this compound was itself rapidly oxidized. Fluoroacetate was partially inhibitory (Table 7) but growth, though somewhat retarded, was still possible in the presence even of $10^{-2} \mathrm{M}$ fluoroacetate.

\section{DISCUSSION}

Arthrobacter globiformis is an obligate aerobe and it is uncertain whether its inability to ferment glucose is merely due to its not possessing a means for anaerobic oxidation of DPNH. Aerobically, the glucose-6-phosphate produced by the constitutive hexokinase is metabolized by both EMP and HMP pathways, the former predominating in non-dividing suspensions. The resulting pyruvate is further oxidized, possibly by a lipoic acid-dependent (i.e. arsenitesensitive) mechanism to yield acetyl-CoA which enters the TCA cycle. Ultimate electron transport to oxygen is probably mediated by a cytochrome system. It was therefore to be expected that, as glucose seems to be utilized by $A$. globiformis by routes also available to Escherichia coli, their molar growth yields on limiting concentrations of the sugar might be very similar. The finding that they were would, however, seem to refute the suggestion that $A$. globiformis is usually well ' adapted to produce the largest amount of growth and to obtain the greatest amount of energy possible from a minimum quantity of sugar' (Conn \& Darrow, 1934).

According to Winogradsky (1925) there exists in all soils an indigenous (autochthonous) microflora whose population remains relatively stable and whose members lead a comparatively unspectacular existence; this in contrast to the zymogenous microflora whose members flourish only when the soil is enriched with extraneous nutrients and whose numbers are liable to quite dramatic fluctuations. If a real distinction between these two groups is possible, the subsistence of the autochthonous organism in the poorer soils could be a consequence of: $(a)$ simple nutritional requirements; $(b)$ ability to use such substrates as are present at greatly subnormal concentrations; $(c)$ extraordinary efficiency of utilization of substrates; $(d)$ greater adaptability with consequent ability to utilize compounds that are unavailable to members of the zymogenous group.

If all members of the genus Arthrobarter are also members of the autochthonous group of soil micro-organisms then simplicity of nutritional requirements cannot be a characteristic of such organisms for several species, e.g. $A$. citreus and $A$. terregens, are highly exacting. Nor, it now appears, if $A$. globiformis itself is truly representative of autochthonous bacteria in general, can these be considered to be more efficient in their utilization of substrates, at least of glucose. As an extension of the original concept of 'microbes humivores' (Winogradsky, 1925) the suggestion has been made that autochthonous organisms maintain themselves in fallow soils by virtue of their ability to utilize constituents of humic material that are unavailable to other organisms. A. globiformis does in fact utilize a wide variety of substances for growth and oxidizes many more. Yet so do those pseudomonads whose fluctuating soil 
populations would characterize them as belonging to the zymogenous group. It may therefore be true that although 'this broad grouping of soil bacteria seems fundamental it bears no direct relation to ability to grow on laboratory media' (Conn, 1948).

I am very grateful to Professor D. D. Woods, F.R.S., for his interest and advice. The work was aided by a grant to the Department from the Rockefeller Foundation.

\section{REFERENCES}

Adams, E. (1954). The enzymatic synthesis of histidine from histidinol. J. biol. Chem. 209, 829.

Berenblum, I. \& Chain, E. (1938). Xl. An improved method for the colorimetric determination of phosphate. Biochem. J. 32, 295.

ConN, H. J. (1928). Certain abundant non-spore-forming bacteria in soil. $Z \mathbf{Z b l}$. Bakt. (2. Abt.), 76, 65.

Conn, H. J. (1948). The most abundant groups of bacteria in soil. Bact. Rev. 12, 257.

Conn, H. J. \& Darrow, M. A. (1934). An extremely economical sugar fermentation. J. Bact. 27, 51.

Cons, H. J. \& Darnow, M. A. (1935). Characteristics of certain bacteria belonging to the autochthonous microflora of soil. Soil Science, 39, 95.

Conn, H. J. \& Dimmick, I. (1947). Soil bacteria similar in morphology to Mycobacterium and Corynebacterium. J. Bact. 54, 291.

Dagley, S., Fewster, M. E. \& Happold, F. C. (1952). The bacterial oxidation of phenylacetic acid. J. Bact. 63, 327.

Dawes, E. A. \& Holms, W. H. (1958a). Metabolism of Sarcina lutea. I. Carbohydrate oxidation and terminal respiration. J. Bact. 75, 390.

Dawes, E. A. \& Holms, W. H. (1958b). Metabolism of Sarcina lutea. II. Isotopic evaluation of the routes of glucose utilization. Biochim. biophys. Acta, $29,82$.

Dawes, E. A. \& Holys, W. H. (1959). On the quantitative evaluation of routes of glucose metabolism by the use of radioactive glucose. Biochim. biophys. Acta, 34, 551 .

Dische, Z. (1953). Qualitative and quantitative colorimetric determination of heptoses. J. biol. Chem. 204, 983.

Dixon, M. (1955). Lactic dehydrogenase from yeast. In Methods in Enzymology, 1, 444. Ed. S. P. Colowick \& N. O. Kaplan. New York: Academic Press Inc.

Dubos, R. \& Miller, B. F. (1937). The production of bacterial enzymes capable of decomposing creatinine. J. biol. Chem. 121, 429.

Francis, G. E., Mulligan, W. \& Wormale, A. (1954). Isotopic Tracers, p. 296. London: The University of London, Athlone Press.

Friedrmane, 'T. E. \& Haugen, G. E. (1943). Pyruvic acid. II. The determination of keto acids in blood and urine. J. biol. Chem. 147, 415 .

Ghiretti, F. \& Barron, E. S. G. (1954). The pathway of glucose oxidation in Corynebacterium creatinovorans. Biochim. biophys. Acta, $15,445$.

Goodwin, 'T. W. \& Williams, G. R. (1952). Studies in vitamin A. 18. The effect of vitamin $A$ deficiency on the pyruvate and $\alpha$-ketoglutarate levels of rat blood. Biochem. J. 51, 708.

Hist., R. I. \& Mrr.s, R. C. (1954). The anaerobic glucose metabolism of Bacterium tularense. Arch. Biochem. Biophys. 53, 174.

KreBs, H. A. (1938). Micro-determination of $\alpha$-ketoglutaric acid. Biochem. J. 32, 108.

Krebs, H. A. \& EgGlestox, L. V. (1939). Bacterial urea formation (metabolism of Corynebacterium ureafaciens). Enzymologia, 7, 310. 
LAscelles, J. (1956). The synthesis of porphyrins and bacteriochlorophyll by cell suspensions of Rhodopseudomonas spheroides. Biochem. J. 62, 78.

Lowry, O. H., Rosebrough, N. J., Farr, A. L. \& Randall, R. J. (1951). Protein measurement with the Folin phenol reagent. J. biol. Chem. 193, 265.

Mornis, J. G. \& WooDs, D. D. (1959). Inter-relationships of serine, glycine and vitamin $B_{6}$ in the growth of mutants of Escherichia coli. J. gen. Microbiol. 20, 576.

Nelson, N. (1944). A photometric adaptation of the Somogyi method for the determination of glucose. J. biol. Chem. 153, 375.

Neuberg, C., Lustig, H. \& Rothenberg, M. A. (1944). Fructose-1: 6-diphosphoric acid and fructose-6-monophosphoric acid. Arch. Biochem. 3, 33.

Russell, J. A. (1944). The colorimetric estimation of small amounts of ammonia by the phenol-hypochlorite reaction. J. biol. Chem. 156, 457 .

Sacks, L. E. (1954). Observations on the morphogenesis of Arthrobacter citreus, spec.nov. J. Bact. 67, 342.

Sakami, W. (1955). Handbook of Isotope Tracer Methods, p. 6. Cleveland: Western Reserve University.

Sauros, P. L. (1955). Microbial transformation of the tobacco alkaloids. I. Cultural and morphological characteristics of a nicotinophile. J. Bact. 69, 28.

SNell, E. E. \& Rannefeld, A. N. (1945). The vitamin $B_{6}$ group. III. The vitamin activity of pyridoxal and pyridoxamine for various organisms. J. biol. Chem. $157,475$.

Sundman, V. (1958). Morphological comparison of some Arthrobacter species. Canad. J. Microbiol. 4, 221.

'TAyLOR, C. B. (1938). Further studies of Bacterium globiforme and the incidence of this type of organism in Canadian soils. Soil Sci. 46, 307.

'Taylor, C. B. \& Lochhead, A. G. (1937). A study of Bacterium globiforme Conn in soils differing in fertility. Canad. J. Res. [C], 15, 340.

Taylor, J. F. (1955). Aldolase from muscle. In Methods in Enzymology, 1, p. 310. Ed. S. P. Colowick \& N. O. Kaplan. New York: Academic Press Inc.

Wang, C. H., Stern, I., Gilmour, C. M., Kiungsoyr, S., Reed, D. J., Bialy, J. J., Christensen, B. E. \& Cheldelin, V. H. (1958). Comparative study of glucose catabolism by the radiorespirometric method. J. Bact. 76, 207.

Winogradsky, S. (1925). Études sur la microbiologie du sol. I. Sur la méthode. Ann. Inst. Pasteur, 39, 299.

Woon, W. A. (1955). Pathways of carbohydrate degradation in Pseudomonas fluorescens. Bact. Rev. 19, 222.

Wood, W. A. \& Schwerdt, R. F. (1953). Carbohydrate oxidation by Pseudomonas fluorescens. I. The mechanism of glucose and gluconate oxidation. J. biol. Chem. 201, 501.

Wood, W. A. \& Schwerdt, R. F. (1954). Carbohydrate oxidation by Pseudomonas fluorescens. II. Mechanism of hexose phosphate oxidation. J. biol. Chem 206. 625.

(Received 9 October 1959) 